\title{
Application of GPR and ERT methods for recognizing of gypsum deposits in urban areas
}

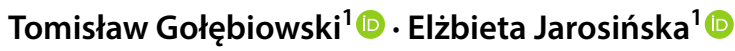

Received: 28 April 2019 / Accepted: 27 September 2019 / Published online: 8 October 2019

(C) The Author(s) 2019

\begin{abstract}
This paper presents the selected results of GPR (ground penetrating radar) and ERT (electrical resistivity tomography) surveys carried out on the sites in Poland where shallow karst forms were found in gypsum deposits. The aim of the surveys was the noninvasive detection of karst forms as well as weathered and fractured bedrock which may threaten the stability of the surface and, consequently, may cause damage to buildings, as well as overground and underground infrastructure. The geophysical surveys were conducted at a depth of only a few meters, i.e., to the depth of buildings foundations. GPR surveys were carried out in short-offset reflection profiling mode with standard orientation of the antennae set; however, on one site, different orientations of antennae were tested. During ERT surveys, different measurement arrays were applied in order to analyze which array was optimal for the detection of karst forms as well as weathered and fractured bedrock. Complex interpretation of geophysical surveys resulted in reduced ambiguity and revealed some regions, dangerous for surface stability. Due to the fact that gypsum deposits were investigated to the depth of maximum $10 \mathrm{~m}$; therefore, hydrological processes were analyzed in the paper instead of hydrogeological processes.
\end{abstract}

Keywords Geophysical methods · GPR · ERT · Gypsum karst · Karst hydrology

\section{Introduction}

Karst phenomena occur in limestone and evaporate like salt and gypsum deposits. The limestone karst occurring in Poland is well recognized and described in geological and geophysical literature. Typically, authors focused on gypsum karst which has been considerably less studied than limestone karst.

The increased spatial development of cities and villages has meant that more and more new buildings are located in areas where karst phenomena occur. The presence of shallow karst forms as well as weathered and fractured bedrock often causes damage to buildings and other overground and underground infrastructure. In order to ensure the safety of people and property, it is necessary to investigate the geological medium using invasive geological and geotechnical techniques and/or noninvasive geophysical surveys.

Tomisław Gołębiowski

goleb@wis.pk.edu.pl

1 Faculty of Environmental Engineering, Cracow University of Technology, Warszawska 24, 31-155 Kraków, Poland
The application of methods of engineering geophysics for the investigation of gypsum deposits is novel in Polish geophysics and, to date, only a few works concerning this problem have been published, notably Łój et al. (2014), Porzucek et al. (2018), and Rudzki (2015). Among the wide range of geophysical techniques for high-resolution imaging of karst forms occurring up to a depth of approximately $10 \mathrm{~m}$ (i.e., to the depth of buildings foundations), the GPR (ground penetrating radar) technique seems to be the most appropriate. This technique allows for fast and inexpensive investigation of the geological medium with a resolution of a few centimeters. In addition, the electrical resistivity tomography (ERT) methods were used, resulting in thorough investigations which reduced interpretation ambiguity.

Geophysical literature contains applications of the abovementioned geophysical methods for the examination of gypsum deposits and gypsum karst. In a paper by Manoutsoglou et al. (2010), the ERT method in combination with a detailed geological investigation was tested as tool for the mapping of gypsum/anhydrite transition zones. Derobert and Abraham (2000) present a combination of the GPR reflection method and seismic imaging (tomography) performed in a gypsum quarry. In a paper by Ulugergerli and Akca 
(2006), the existence of cavities and weak zones in gypsum was explored using ERT, GPR and seismic refraction methods. Prokhorenko et al. (2006) explored the GPR reflection technique for the detection of caves and galleries in gypsum deposits as well as for searching of discontinuities and cracks in rocks. McCormack et al. (2017) demonstrated the use of ERT and discrete conduit network modelling to characterize the hydrogeology of the catchment by determining flow pathways and their likely hydraulic mechanisms. Chalikakis et al. (2011) presented a profound and thorough overview of the application of different geophysical methods to karst system exploration. In this work, the author utilized GPR, ERT, CSAMT (controlled source audio magneto-telluric method), VLF (very low frequency method), seismic tomography, MASW (multichannel analysis of surface waves method) and microgravimetry methods for the examination of karst forms.

The shallow karst forms as well as weathered and fractured bedrock analyzed in this paper were created by weathering processes and mainly by infiltration of surface water to the rock mass; therefore, the authors focused on karst hydrology instead of karst hydrogeology. Karst hydrology was a subject of interest of several authors; e.g., in a paper by Silverii et al. (2019), GPS time series and hydrological data from a tectonically active region in the Apennines, hosting large karst aquifers, were analyzed. Stokes et al. (2010) analyzed cases when allogenic water, which can be very aggressive (i.e., acidic), infiltrated into the rock mass from non-karst wetlands or bogs; when such water encounters carbonate bedrock, it can result in more intensive karst development. In their paper, Ługowski et al. (2016) described unique relief features, occurring near Lviv (Ukraine), called "hydration domes," which were formed due to weathering (hydration) of anhydrite and its transformation into gypsum. Watlet et al. (2018) clam that water infiltration and recharge processes in karst systems are complex and difficult to measure with conventional hydrological methods; therefore, the authors proposed the analyses of time-lapse 2D ERT surveys carried out over a period of 3 years.

Considering the aim of the paper, the authors focused mainly on the analysis of geological information for gypsum deposits exposed on the surface or located within a few meters of depth. Information concerning gypsum deposits was gathered from the following papers: Fils (1954), Babel (1999), Bąbel et al. (2015) and Urban et al. (2015). Karst phenomenon occurring in gypsum, in a chemical sense, is the dissociation in aqueous solution of calcium sulfate. This process is, therefore, much simpler than the dissolving of carbonates (e.g., limestones) where additional presence of carbon dioxide in water is needed. Karst process of gypsum is also much faster than in limestone, because gypsum at room temperature is more than one hundred times more soluble than calcite. The gypsum karst is considered an effect of the preglacial processes and variously developed forms of gypsum karst occur in Poland in the southern part of the Nida river area, also called the Nida gypsum area (Fig. 1). The analyzed region is a Jurassic syncline filled with the Cretaceous and partly Miocene age material. Among the Miocene deposits, there are layers of gypsum, partly clayey, created in the shallow Miocene sea. According to Fils (1954), karst forms created due to surface leaching are very rare, and the erosion of gypsum takes place much faster as a result of rock exfoliation. Dissolving of gypsum by water can lead to the formation of karst forms only in places where water is exposed to gypsum for a long time, e.g., in depressions and under the soil covered by weathered/fractured gypsum. In the Quaternary period, the analyzed region was covered by a glacier, and as a result, gypsum was covered by the Pleistocene tills, clays, gravels and sands. Quaternary deposits may fill fractures and karst forms and, consequently, petrophysical parameters of such regions will change markedly. In the Nida gypsum area, the processes of gypsum weathering and karsting are still on-going and even during a human lifetime, and new karst forms may appear and threaten the surface stability.

For the geophysical surveys, three sites where gypsum outcrops occurred or the gypsum roof was covered by thin layer of Quaternary deposits were chosen (Fig. 1c), i.e., the Siesławice, Wiślica and Staszów sites.

\section{Geophysical surveys}

In geophysics, karst forms as well as weathered and fractured zones in bedrock are treated as voids with different shapes, filled with air/water or sometimes colmatated with Quaternary deposits, i.e., usually a postglacial mixture of sand and clay. If voids are filled with air or water, the contrast of selected petrophysical parameters between solid rock mass (i.e., gypsum) and karst forms is high (Table 1). The high contrast of the aforementioned parameters enables easier detection of karst forms in gypsum using GPR and ERT methods. Contrast of petrophysical parameters becomes lower if voids are filled with Quaternary deposits (Table 1) or when voids are backfilled with gypsum debris. In such situations, karst forms still occur in the rock mass but their detection using of geophysical methods may be difficult or even impossible.

It is well known that electrical parameters of rocks (e.g., gypsum) depend strongly on porosity, distribution of fractures, degree of weathering as well as volume and type of medium filling the free spaces (Table 1). In a paper by Guinea et al. (2010), the authors analyzed the changes of electrical resistivity of gypsum, depending on the purity of the rock; the purity was defined as amount of clay in the samples of gypsum (Fig. 2a). In Fig. 2b, the results of the numerical modelling, laboratory tests and ERT surveys presented in paper by Guinea et al. (2010) are shown and this 
A

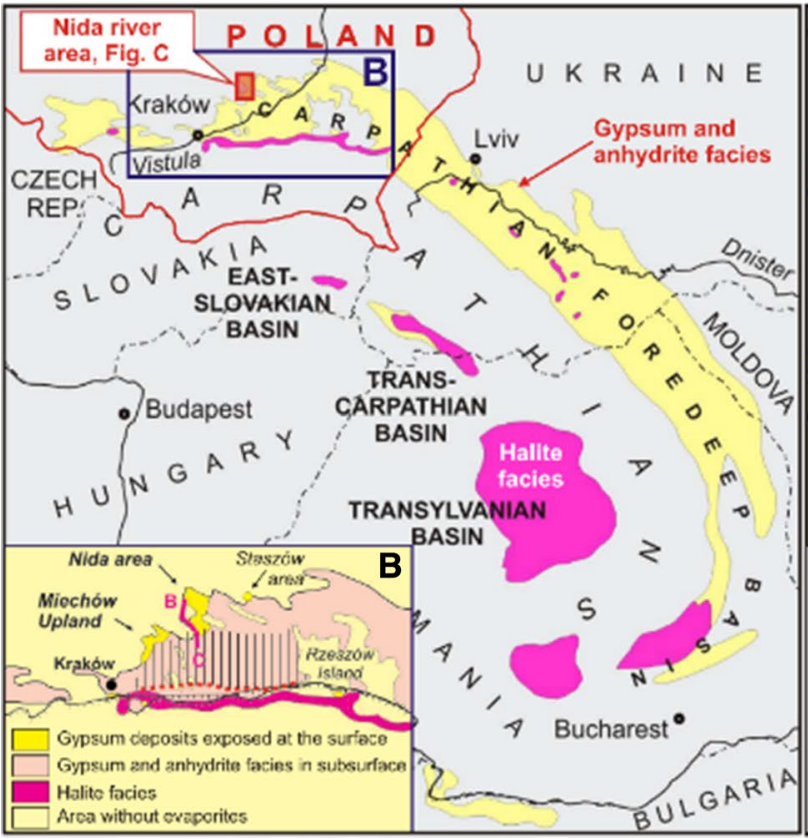

C

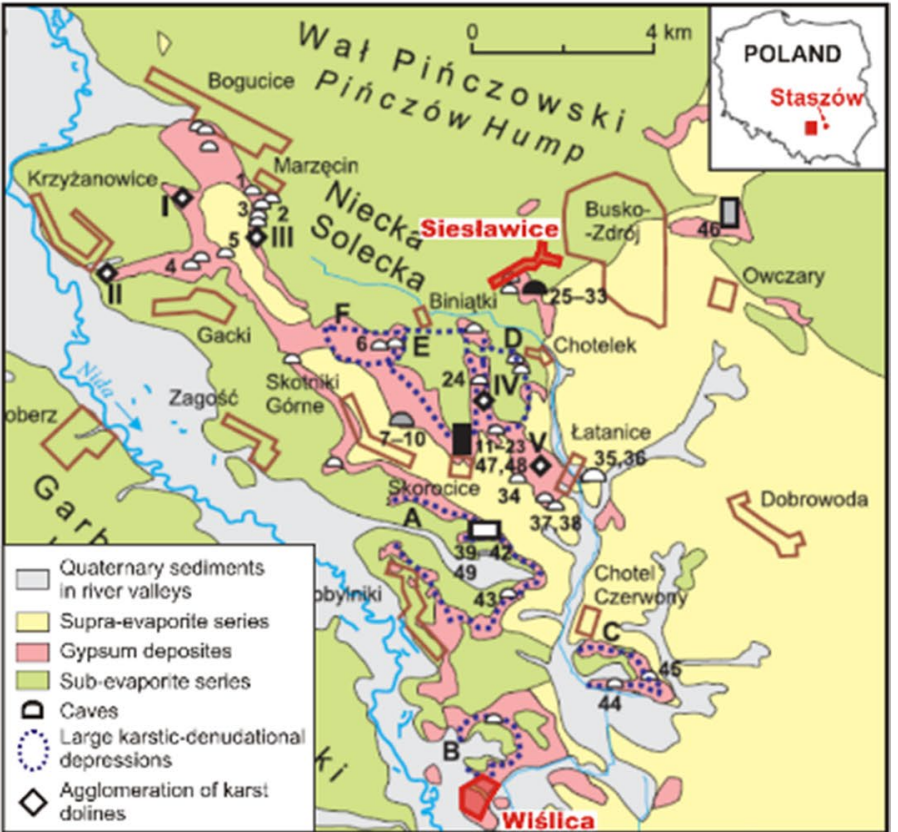

Fig. 1 a, b Present-day distribution of the Badenian evaporites (Bąbel et al. 2015); c Geological map of the Nida gypsum area, without Pliocene and Quaternary cover (Urban et al. 2015)

Table 1 Average values of electrical parameters on the basis of works conducted by Annan (2001), Plewa and Plewa (1992), Drozdzak and Twardowski (2010) and Guinea et al. (2010)

\begin{tabular}{lll}
\hline Medium & $\begin{array}{l}\text { Relative electrical permit- } \\
\left.\text { tivity } \varepsilon_{r}[-] *^{*}\right)\end{array}$ & $\begin{array}{l}\text { Electrical } \\
\text { resistivity } \rho \\
{[\Omega \mathrm{m}]}\end{array}$ \\
\hline Gypsum & 7 & $10^{3}$ \\
Air & 1 & $10^{9}$ \\
$\begin{array}{l}\text { Fresh water (from pre- } \\
\text { cipitation and melted }\end{array}$ & 80 & $10^{-2}$ \\
$\begin{array}{l}\text { snow) } \\
\begin{array}{l}\text { Dry quaternary depos- } \\
\text { its (mixture of sand } \\
\text { and clay) }\end{array}\end{array}$ & 9 & $10^{2}$ \\
\hline
\end{tabular}

*Relative electrical permittivity $\varepsilon_{\mathrm{r}}$ was defined as $\varepsilon_{\mathrm{r}}=\varepsilon / \varepsilon_{0}$ where $\varepsilon$ was the electrical permittivity of the medium and $\varepsilon_{0}$ was the electrical permittivity of the vacuum (i.e., $8.85 \times 10^{-12} \mathrm{~F} / \mathrm{m}$ )

information will be used subsequently in this paper, as part of the interpretation of the geophysical surveys.

The first consideration when applying geophysical methods for the detection of karst forms as well as weathered and fractured zones in bedrock, as alluded to above, is the contrast of petrophysical (for GPR and ERT method-electrical) parameters. The second consideration is the resolution and depth range of the various geophysical methods. As mentioned in the introduction, the noninvasive surveys were carried out to the depth of a few meters (max. $10 \mathrm{~m})$ and in such situations, the most important aspect was the high resolution rather than depth range. Therefore, the high-resolution GPR method was chosen as the primary measurement technique and as an auxiliary method, the ERT technique was proposed. The ERT method has a lower resolution than the GPR method but in areas where gypsum rock will contain clay materials, the electrical resistivity decreases (Fig. 2b) and, consequently, the attenuation of electromagnetic waves increases, according to the formula (1). In such areas, only complex GPR and ERT interpretation should deliver satisfactory results.

$\alpha=2 \pi f \sqrt{\left(\frac{\varepsilon \cdot \mu}{2}\right) \cdot\left(\sqrt{1+\delta^{2}}-1\right)} \quad$ where $\tan (\delta)=\frac{\sigma+\omega \varepsilon^{\prime \prime}}{\omega \varepsilon^{\prime}}$

where $\alpha$ is attenuation factor; $f$ is frequency of transmitter antenna (Tx); $\varepsilon, \varepsilon^{\prime}, \varepsilon^{\prime \prime}$ are electrical permittivity and real and imaginary parts of $\varepsilon ; \mu$ is magnetic permittivity; $\delta$ is loss angle; $\sigma$ is electrical conductivity.

Terrain surveys were carried out with the use of Swedish georadar PROEX and Ukrainian georadar VIY. For the measurements, $70 \mathrm{MHz}, 250 \mathrm{MHz}$ and $500 \mathrm{MHz}$ shielded, bistatic antennae were used. GPR surveys were carried out in 2D mode, using the short-offset reflection technique. Traces were recorded alongside the profiles every $0.02 \mathrm{~m}$ (for $500 \mathrm{MHz}$ antennae), $0.05 \mathrm{~m}$ (for $250 \mathrm{MHz}$ antennae) and $0.2 \mathrm{~m}$ (for $70 \mathrm{MHz}$ antennae). Stacking equal to 8-times or 16-times (depending on location) was applied to increase the signal/noise ratio. 
A

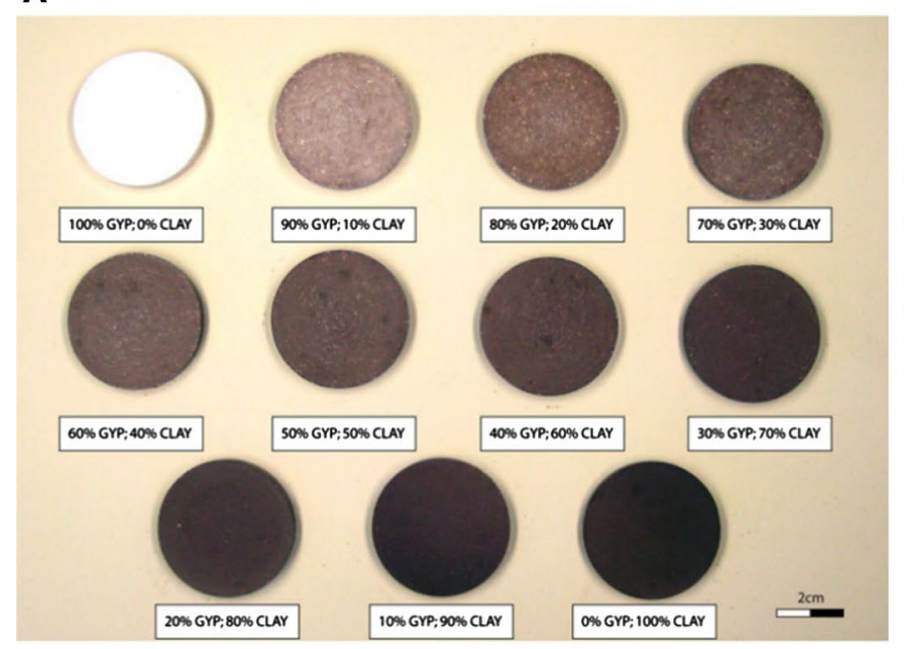

B

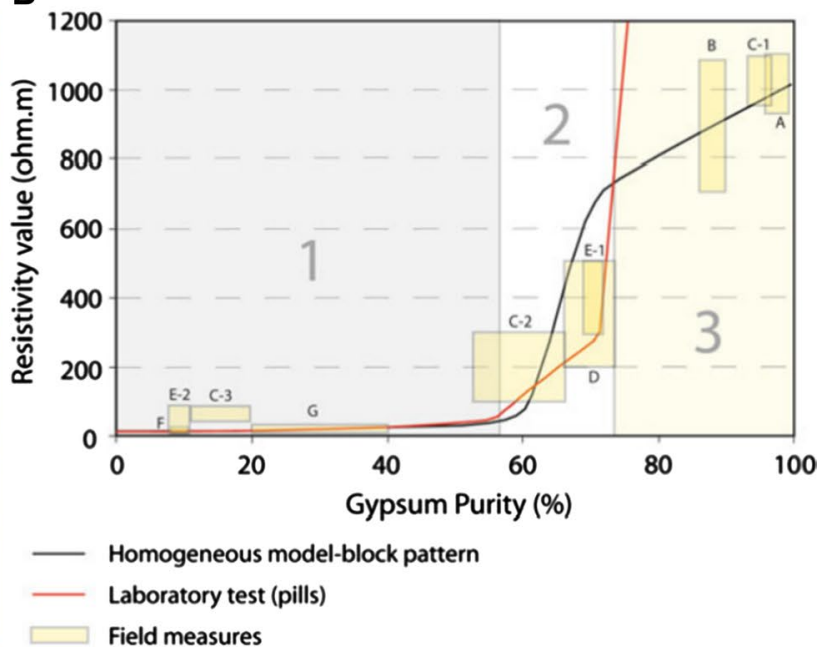

Fig. 2 a Sample pills made using mixtures of powdered gypsum rock and clay; b Graph combining the results of numerical modelling, laboratory tests and electrical resistivity values measured in the field; a

In all sites, a standard orientation of transmitter antenna (Tx) and receiver antenna (Rx), i.e., co-pole orientation (Fig. 3-option A1), was assumed. Additionally, on the Staszów site, different orientations of antennae, i.e., co-pole, cross-pole and end-fire orientations (Fig. 3), were adopted. When using the reflection technique, electromagnetic wave, propagating in the examined medium according to wave Eq. (3), is reflected from karst forms. The reflection coefficient depends on the contrast of electrical properties and polarization of the electromagnetic wave which is linked with orientation of antennae in relation to the geometry and distribution of underground objects. The reflection coefficients are different $(4,5)$ for the cases when the electric field component $E$ in electromagnetic wave is polarized perpendicularly (with antennae in co-pole mode) or parallelly (with antennae in end-fire mode) to the plane/objects of incidence (Daniels et al. 2003). Cross-pole orientation of antennae is a combination of the co-pole and end-fire modes. Application of different antennae orientations (i.e., different wave polarizations) during terrain surveys allowed recording the additional information which was presented and discussed in papers by Daniels et al. (2003), Gołębiowski (2008), Gołębiowski purity of gypsum was defined by amount of clay in gypsum-see figure with signature A (Guinea et al. 2010)

and Tomecka-Suchoń (2012), Guy et al. (1999), Marcak and Gołębiowski (2010) and Roberts and Daniels (1999).

$\nabla^{2} \vec{E}-\mu \sigma \cdot \frac{\partial \vec{E}}{\partial t}-\varepsilon \mu \cdot \frac{\partial^{2} \vec{E}}{\partial t^{2}}=0$

$R_{\perp}=\frac{\cos (\theta)-\mid \sqrt{\frac{\varepsilon_{2}}{\varepsilon_{1}} \cdot \sqrt{1-\left(\frac{\varepsilon_{1}}{\varepsilon_{2}} \cdot \sin ^{2}(\theta)\right)} \mid}}{\cos (\theta)+\left|\sqrt{\frac{\varepsilon_{2}}{\varepsilon_{1}} \cdot \sqrt{1-\left(\frac{\varepsilon_{1}}{\varepsilon_{2}} \cdot \sin ^{2}(\theta)\right)}}\right|}$
$R_{\|}=\frac{-\cos (\theta)+\left|\sqrt{\frac{\varepsilon_{1}}{\varepsilon_{2}} \cdot \sqrt{1-\left(\frac{\varepsilon_{1}}{\varepsilon_{2}} \cdot \sin ^{2}(\theta)\right)}}\right|}{\cos (\theta)+\left|\sqrt{\frac{\varepsilon_{2}}{\varepsilon_{1}} \cdot \sqrt{1-\left(\frac{\varepsilon_{1}}{\varepsilon_{2}} \cdot \sin ^{2}(\theta)\right)}}\right|}$
A

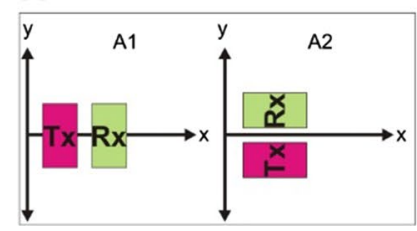

B

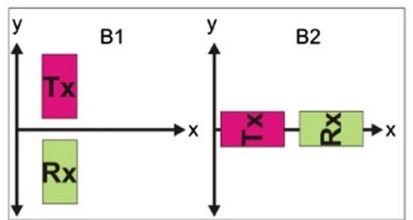

C

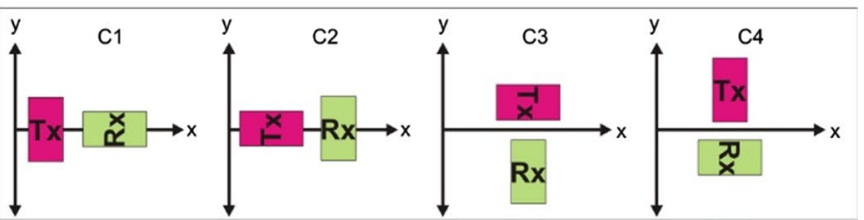

Fig. 3 Different orientations of GPR antennae: a co-pole orientations; $\mathbf{b}$ end-fire orientations; $\mathbf{c}$ cross-pole orientations; $x$-measurement profile direction 
where $\nabla$ is Nabla operator; $\vec{E}$ is electric field component of electromagnetic wave; $\mu$ is magnetic permittivity; $\sigma$ is electrical conductivity; $\varepsilon_{1}$ and $\varepsilon_{2}$ are electrical permittivity of gypsum and void; $t$ is time; $R$ is reflection coefficient; $\theta$ is incident/reflection angle.

The radargrams presented in the paper were shown in two forms, i.e.: as two-dimensional distribution of reflections and three-dimensional distribution of instantaneous amplitudes counted from Hilbert transform. Instantaneous amplitudes may be treated as energy distributions of georadar signals reflected from karst forms existing in gypsum. All radargrams were presented in normalized form, i.e., with amplitudes (energies) normalized to the maximum amplitude (energy) of the direct air wave. For proper time-depth conversion of radargrams, procedure of adaptation of diffraction hyperbolae was performed (ReflexW manual 2018); this procedure was carried out on radargrams recorded in the Siesławice site.

Radargrams were digitally processed using the ReflexW software. The following procedures were applied: $t_{0}$ and topographic corrections, removal of wowing effect, DC correction, Butterworth time-dependent filtration, 1D median filtering, gaining with the use of energy decay function, background removal, stacking, 2D average, spectral whitening and morphologic filtration. A detailed description of the applied procedures as well as a description of the parameters assumed for the aforementioned procedures can be found in publications by Annan (1999), Gołębiowski (2012) and ReflexW Manual (2018).

ERT measurements were taken using an ARES and ARES II device from the Czech company GF Instruments. During terrain surveys, various measurement arrays were tested, such as Dipole-Dipole, Wenner and Shlumberger arrays which are characterized by different measurement parameters (Table 2). The distance between the electrodes was also taken into account, as this impacts the extent of the profile coverage as well as signal sensitivity to vertical and horizontal changes in resistivity. On the Wiślica site, distances of $0.5 \mathrm{~m}, 1 \mathrm{~m}, 1.5 \mathrm{~m}$ and $2 \mathrm{~m}$ between the electrodes were tested; in the Staszów site, distances equal to $2 \mathrm{~m}$ and $4 \mathrm{~m}$ were applied. During ERT surveys, measurement error (or standard deviation) of $2 \%$ was assumed.
ERT data were processed in the $2 \mathrm{D}$ inversion method using Res-2D-Inv software produced by Geotomo Software, applying nonlinear optimization techniques (Loke 2018). At the inversion stage, the limits were applied to the model to eliminate the inverse model solution ambiguity. For this purpose, robust inversion (L1 norm) was selected, as it is preferable in the case of rapid changes in underground object boundaries (i.e., karst forms). The robust inversion includes an iterative algorithm that compares the calculated model with the apparent resistivity measurements and gradually improves the calculated model by the minimization of the sum of the absolute difference (Abs error) between them.

\section{Results from the Siesławice site}

Geophysical surveys in the village of Siesławice were carried out in area without buildings (Fig. 4a), where a gypsum quarry (Fig. 4b) and shallow karst forms (to the depth of approximately $2 \div 3 \mathrm{~m}$ ) are located (Fig. $4 \mathrm{c}$ ).

Two-dimensional, reconnaissance GPR surveys in the Siesławice site were carried out as part of a BSc thesis (Ornacka 2014); at the same time preliminary microgravimetric measurements in 2D mode were taken. The results of the reconnaissance works were presented in a paper by Łój et al. (2014). The results of detailed microgravimetric surveys, carried out along five profiles (Fig. 4b), were presented in a paper by Porzucek et al. (2018).

In this section, the results of detailed 3D GPR surveys are shown. GPR measurements were taken with the use of antennae with a frequency of $500 \mathrm{MHz}$. GPR surveys were conducted in 2D mode but the application of the interpolation procedure enabled the construction of a 3D visualization demonstrating the distribution of anomalies. For proper conversion of the time axis into the depth axis, adaptation of diffraction hyperbolae was carried out (Fig. 5). Analysis of information from Fig. 5 reveals that the velocity of electromagnetic wave varies in a small range, from 0.09 to $0.12 \mathrm{~m} /$ $\mathrm{ns}$; therefore, for the time-depth conversion of radargrams, average velocity equals $0.11 \mathrm{~m} / \mathrm{ns}$ were assumed.

In Fig. 6, the 3D distribution of instantaneous amplitudes (energies), recorded in profiles from 1 to 7 is presented; whereas in Fig. 7, the same visualization for profiles from 8 to 13 is shown. In Figs. 6 and 7, a muting procedure was
Table 2 Basic parameters of measurement arrays in ERT technique (Loke 1999)

\begin{tabular}{llllll}
\hline Measurement array & $\begin{array}{l}\text { Vertical } \\
\text { resolution }\end{array}$ & $\begin{array}{l}\text { Horizontal } \\
\text { resolution }\end{array}$ & $\begin{array}{l}\text { Depth range } \\
\text { versus length of } \\
\text { profile }\end{array}$ & $\begin{array}{l}\text { Distribution of } \\
\text { measurement } \\
\text { points }\end{array}$ & Strength of signal \\
\hline Wenner & High & Low & 0.17 & Low & High \\
Schlumberger & Mean & Mean & 0.19 & Mean & Mean \\
Dipole-Dipole & Low & High & 0.22 & Mean & Low \\
\hline
\end{tabular}



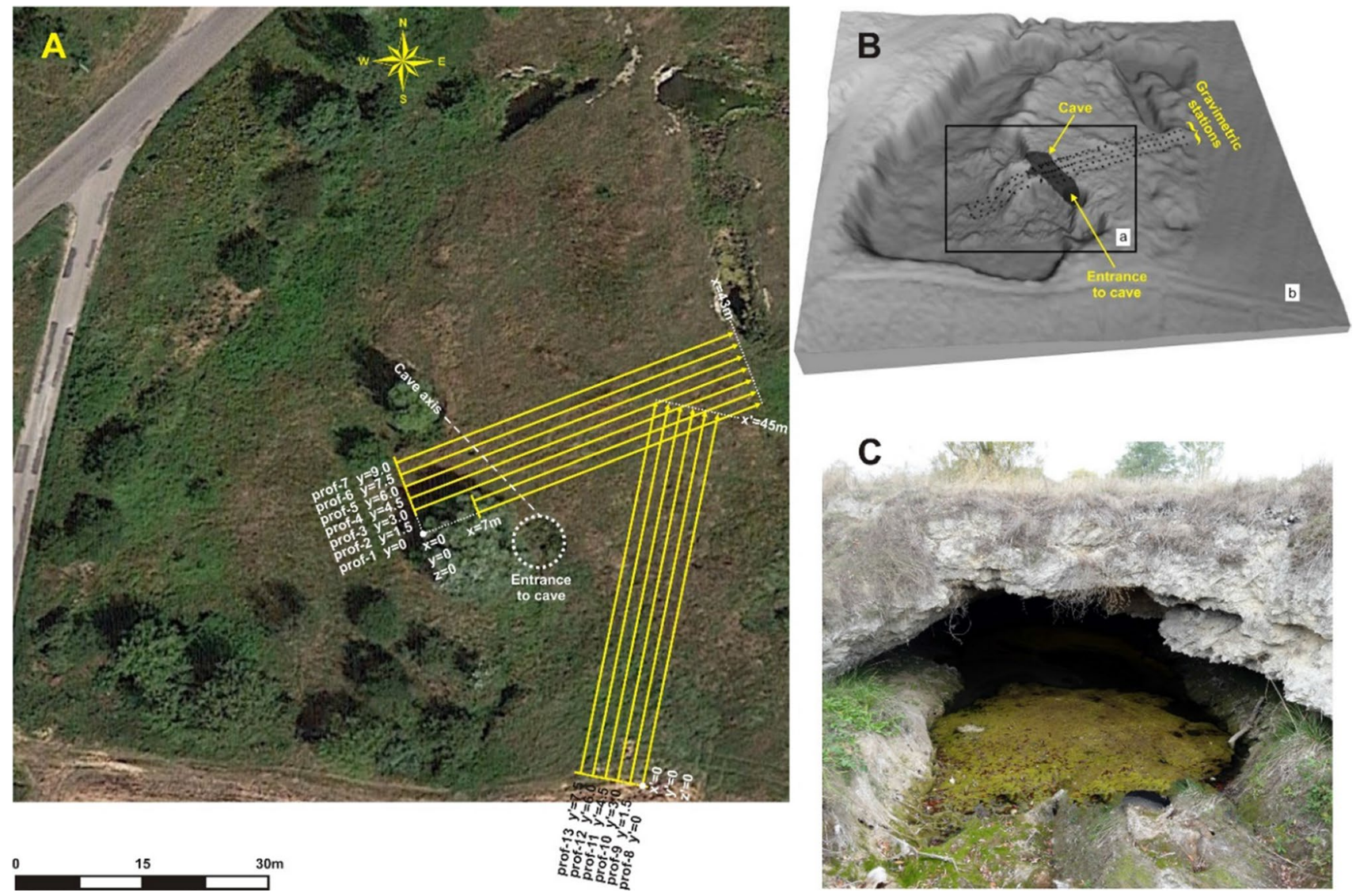

Fig. 4 a Projects of GPR profiles in the Siesławice site (base map: Google Earth Pro program); b Digital terrain model based on integrated data derived from TLS (a) and ALS (b) measurements (Por- zucek et al. 2018); c Entrance to the cave located under the investigation site (Łój et al. 2014)

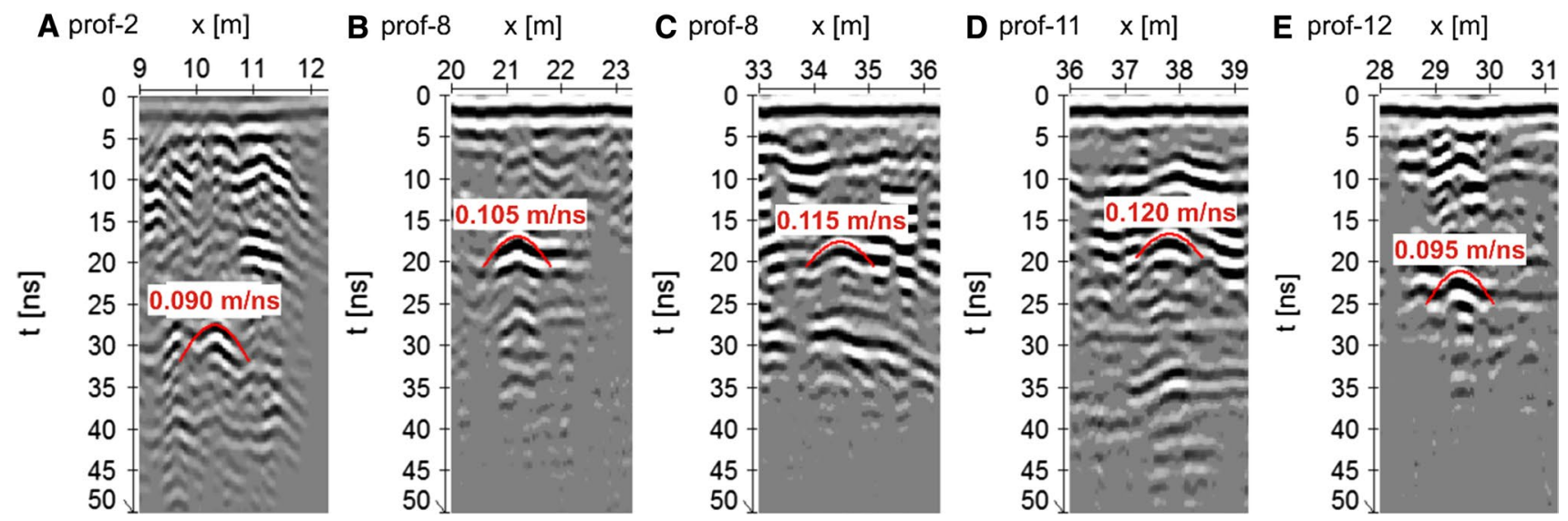

Fig. 5 Results of velocity estimation using the procedure of diffraction hyperbola adaptation

applied for recordings of direct air wave and direct ground wave and for effects generated by anomalies at shallow depths, i.e., to the depth of $0.4 \mathrm{~m}$.

In Fig. 6, it is easily noticed that gypsum on the whole investigation site is highly weathered, to the depth of approximately $0.8 \div 1 \mathrm{~m}$. Locally, a weathered zone is developed vertically to the depth of approximately $1.5 \mathrm{~m}$. The most dangerous area is located between $x=4 \mathrm{~m}$ and $x=11 \mathrm{~m}$, where highly fractured and weather gypsum occurs around the cave. If a building would be located on such area, 


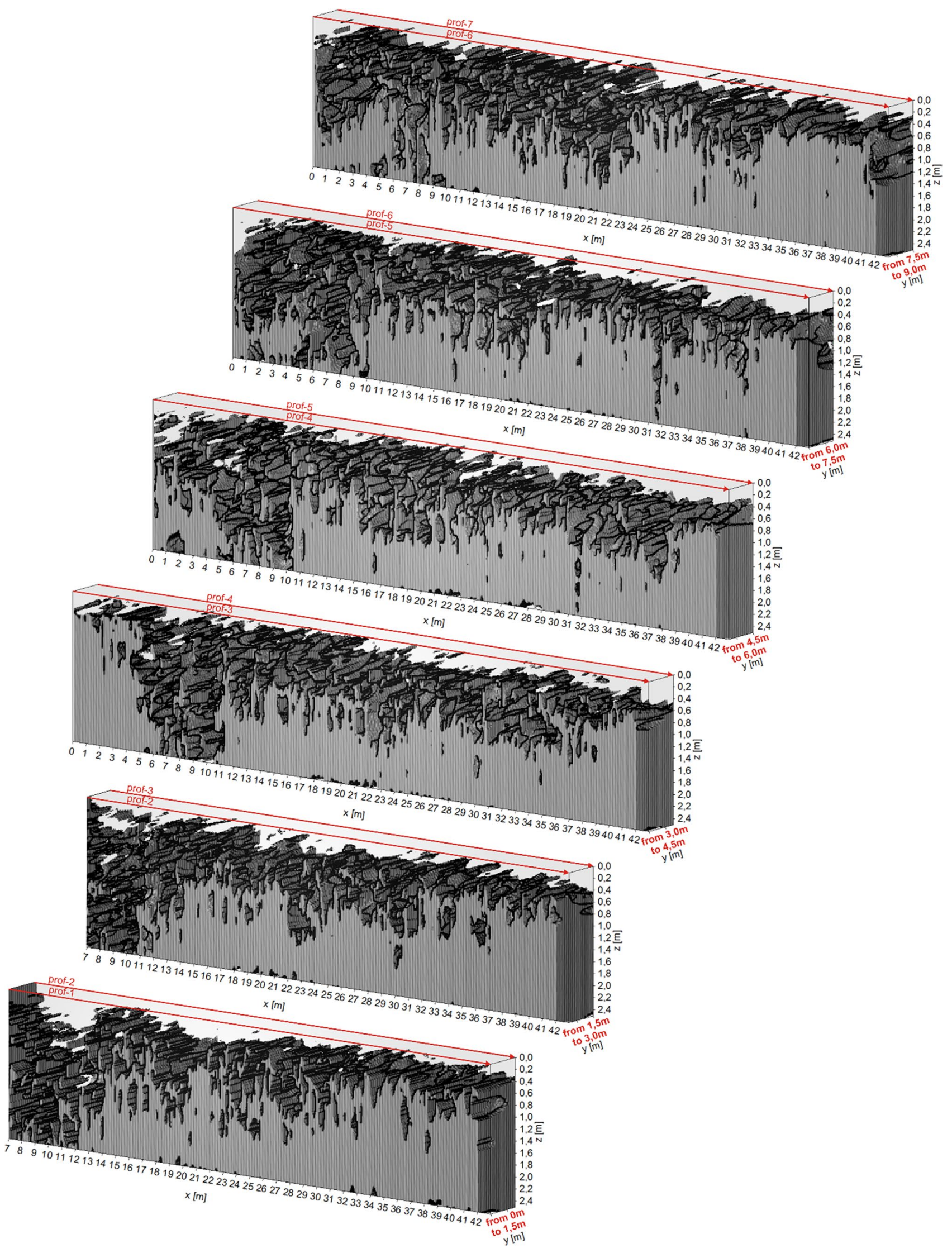

Fig. 6 Radargrams recorded along profiles 1-7 in the form of instantaneous amplitudes distribution 


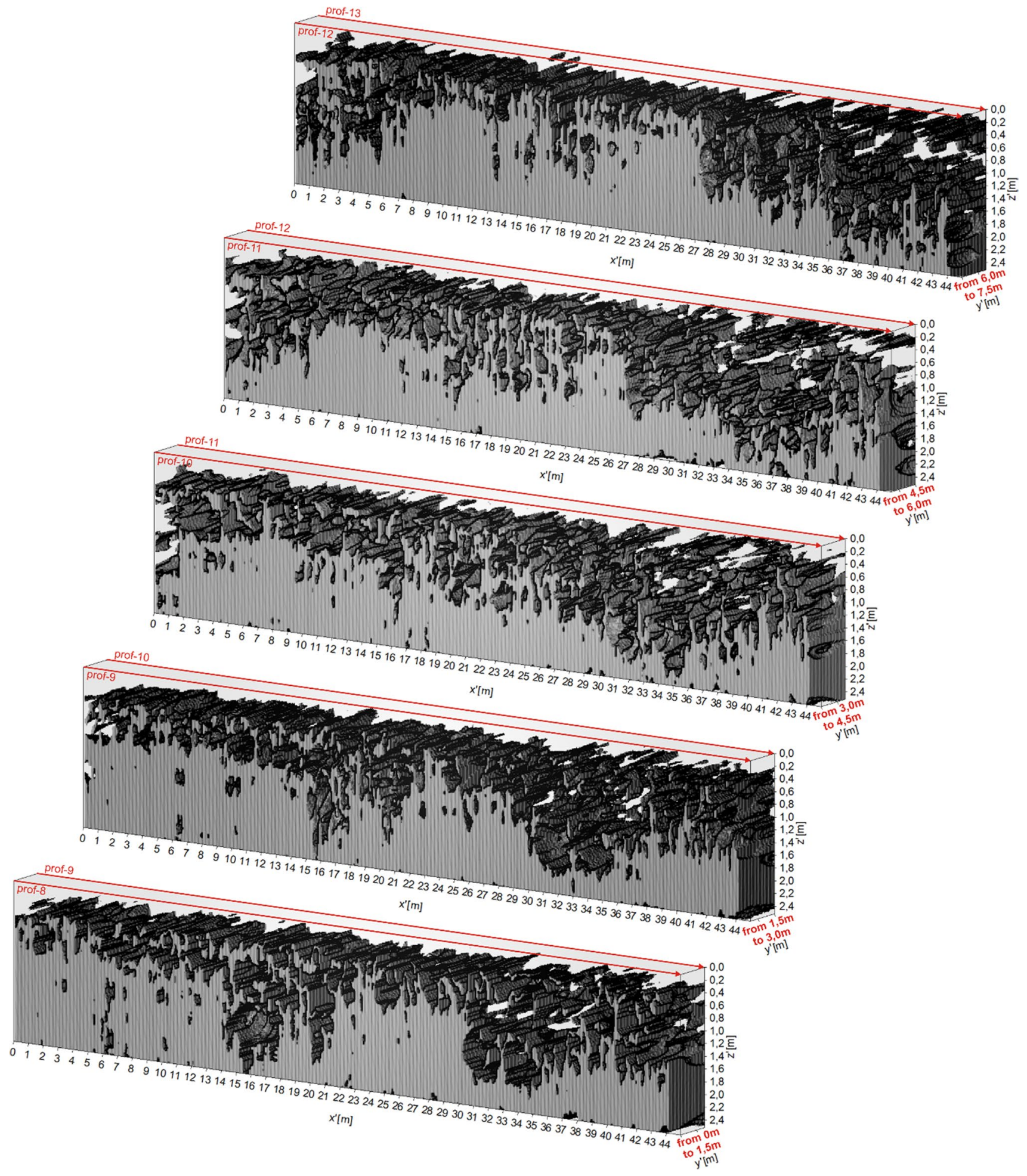

Fig. 7 Radargrams recorded along profiles $8-13$ in the form of instantaneous amplitudes distribution

it is highly probable that it would be damaged due to instability of the geological medium. In addition, in an area of highly weathered gypsum, e.g., $x=0 \div 22 \mathrm{~m}$ along profiles no. $4,5,6,7$, the fissures might appear on the building due to instability of the near surface zone.

The results of the GPR surveys presented in Fig. 7 are similar to those presented in Fig. 6, i.e., highly weathered 
gypsum is observed to the depth of approximately $1.5 \mathrm{~m}$; locally, weathered and probably additionally fractured rock mass is extended to the depth of approximately $2 \mathrm{~m}$, i.e., from $x=14 \mathrm{~m}$ to $x=21 \mathrm{~m}$ (profile no. 8, 9, 10), from $x=0 \mathrm{~m}$ to $x=6 \mathrm{~m}$ (profile no. $11,12,13$ ) and from $x=30 \mathrm{~m}$ to $x=45 \mathrm{~m}$ for all profiles. These areas are the most dangerous for building's stability and for safety of overground and underground infrastructure.

\section{Results from the Wiślica site}

Three-dimensional (3D) geophysical surveys on the Wiślica site (Fig. 8a) were conducted using of ERT, GPR and microgravimetric methods in several stages between 2013 and 2018. The main aim of the investigation was the noninvasive detection of archaeological and historical objects located to the depth of c.a. 2 m under the Salt Square (Pasierb et al. 2014; Cichy 2014; Gołębiowski et al. 2018a), around the Basilica (Cichy 2014; Documentation 2018; Gołębiowski et al. 2018b) and on the Regia site (Gołębiowski 2014). Additionally, two-dimensional (2D) ERT and GPR surveys

A

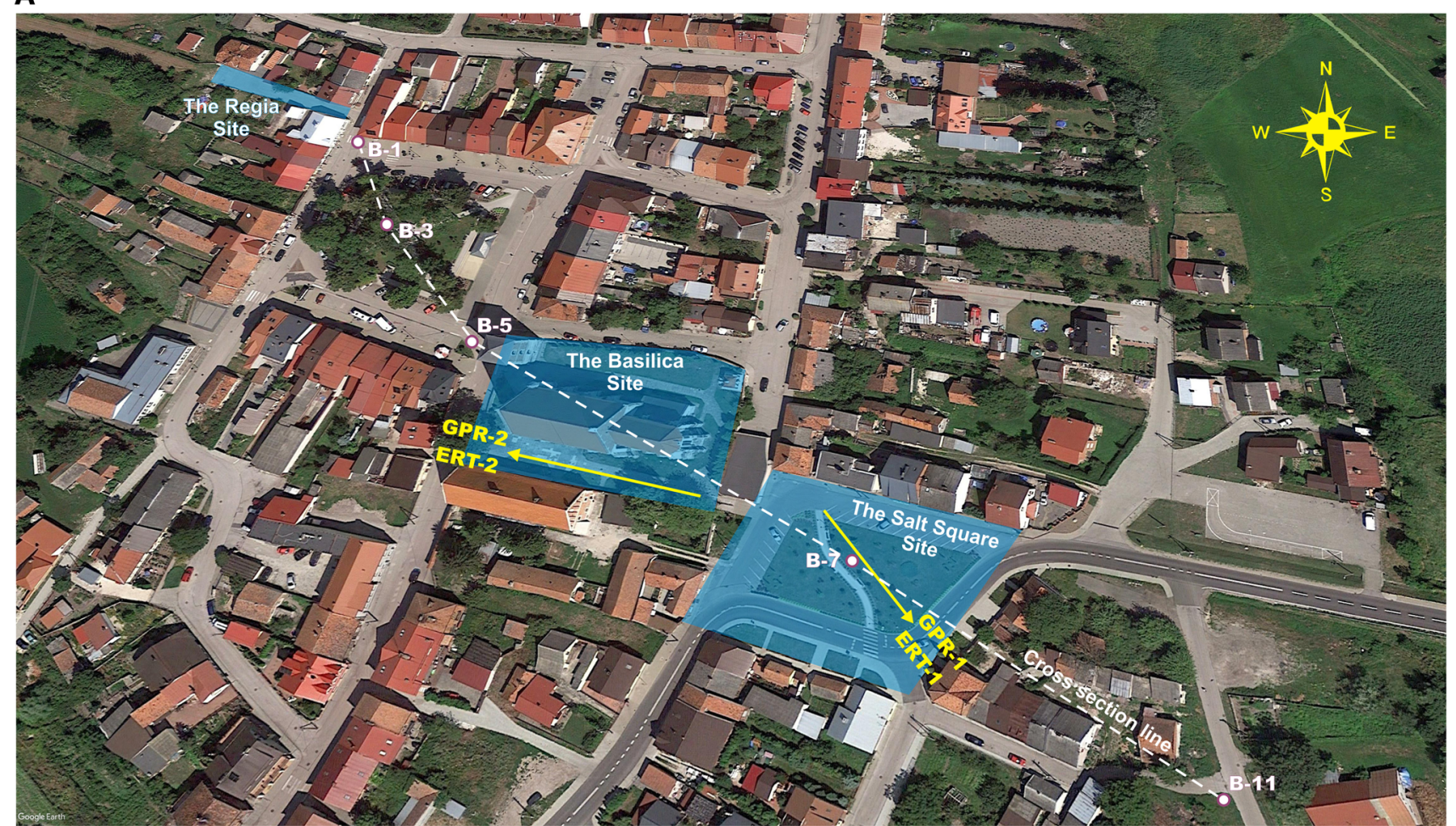

B

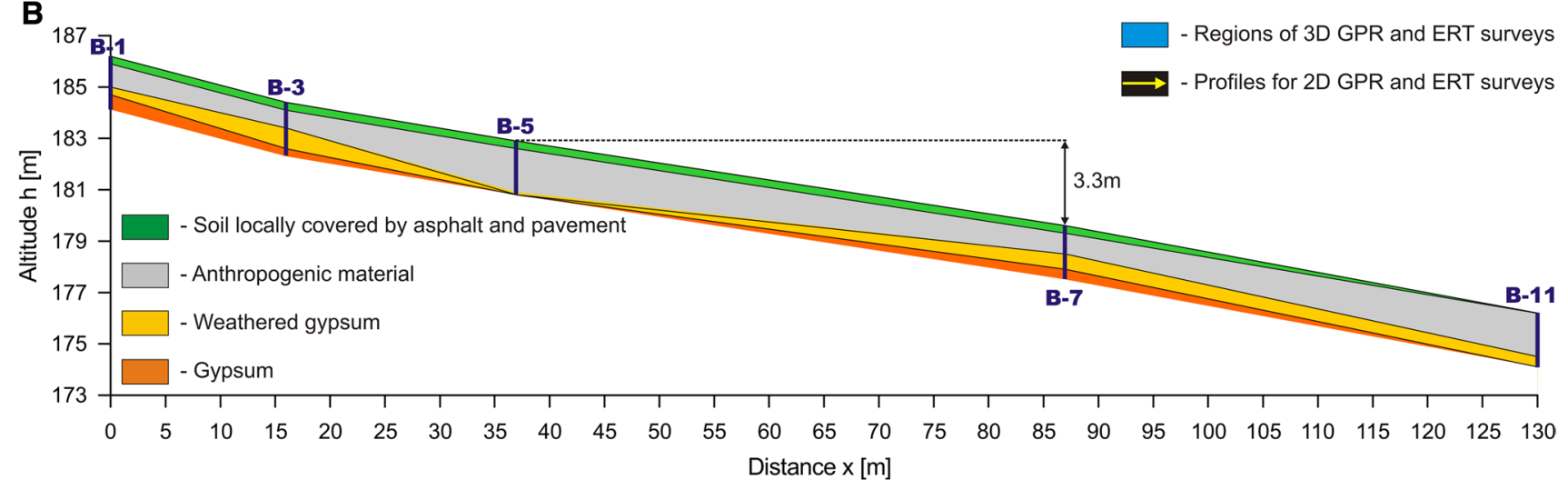

Fig. 8 a Three sites in the village of Wiślica where geophysical surveys were carried out (base map: Google Earth Pro program); b General cross section of the geological medium to the depth of $2 \mathrm{~m}$ (Sowiński 2009) 
were carried out along few profiles in order to recognize gypsum bedrock, to the depth of approximately $10 \mathrm{~m}$; in this section, only selected profiles (Fig. 8a-profiles: GPR-1, ERT-1 and GPR2, ERT-2) designed for deep 2D recognizing of gypsum deposits were analyzed.

On the Wiślica site, the geological medium was recognized to the depth of $2 \mathrm{~m}$ by 14 boreholes (Sowiński 2009). Geological information from boreholes located near the profiles analyzed in this section shows (Fig. 8b) that under a soil and asphalt/pavement, anthropogenic material occurs; under this material, a roof of gypsum rock is located, and the top part of the gypsum is weathered. The GPR and ERT anomalies located in the near surface zone, to the depth of $1.5 \div 2.0 \mathrm{~m}$ were not analyzed, because it is a zone strongly changed by human activity (Fig. 8b).

Velocity of electromagnetic wave for typical gypsum $\left(\varepsilon_{r}=7\right.$-Table 1$)$ is equal $0.113 \mathrm{~m} / \mathrm{ns}$; it was confirmed by velocity analysis (Fig. 5). Velocity for soil and Quaternary deposits $\left(\varepsilon_{r}=9\right.$-Table 1$)$ is equal $0.1 \mathrm{~m} / \mathrm{ns}$. Velocity for anthropogenic material should be similar to velocity of soil and Quaternary deposits. Considering information presented above, for time-depth conversion of all radargrams, mean velocity equals $0.1 \mathrm{~m} / \mathrm{ns}$ was assumed.

The results of 2D GPR and ERT surveys carried out in the Salt Square site (Fig. 8a) are presented in Fig. 9.
In the radargram (Fig. 9a), high-amplitude reflections were recorded to the depth of $7 \div 8 \mathrm{~m}$ in the area between $x=19 \div 38 \mathrm{~m}$; these anomalies could be incorrectly interpreted as the elevation of gypsum bedrock in the second part of the GPR profile; this problem will be resolved by the complex GPR and ERT interpretation.

The results of ERT survey (Fig. 9b) show that the roof of gypsum is located at the depths between 1.7 and $4.0 \mathrm{~m}$. Information from borehole B-7 (Fig. 8b) depicts that the roof of gypsum is located at the depth of $1.7 \mathrm{~m}$, but the top part of rock, between depths $1.1 \div 1.7 \mathrm{~m}$, is weathered. Borehole information correlates well with the result of ERT survey. In the gypsum bedrock, two subzones may be distinguished, i.e., lower resistivity zone (Fig. 9b-yellow color) and higher resistivity zone (Fig. 9b-brown color).

Higher resistivity zone correlates well with high-amplitude reflections, recorded between $x=19 \div 38 \mathrm{~m}$; this zone may be interpreted as fractured gypsum with free spaces filled mainly with air. In higher resistivity zone, high resistivity anomaly (Fig. 9b, red and violet colors) is easily noticed; taking into account information from Table 1 , resistivity for solid gypsum is equal c.a. $1000 \Omega \mathrm{m}$, so high resistivity anomaly, where reflections have low amplitudes (Fig. 9a, between $x=26 \div 31 \mathrm{~m}$ ), depict to the solid gypsum.
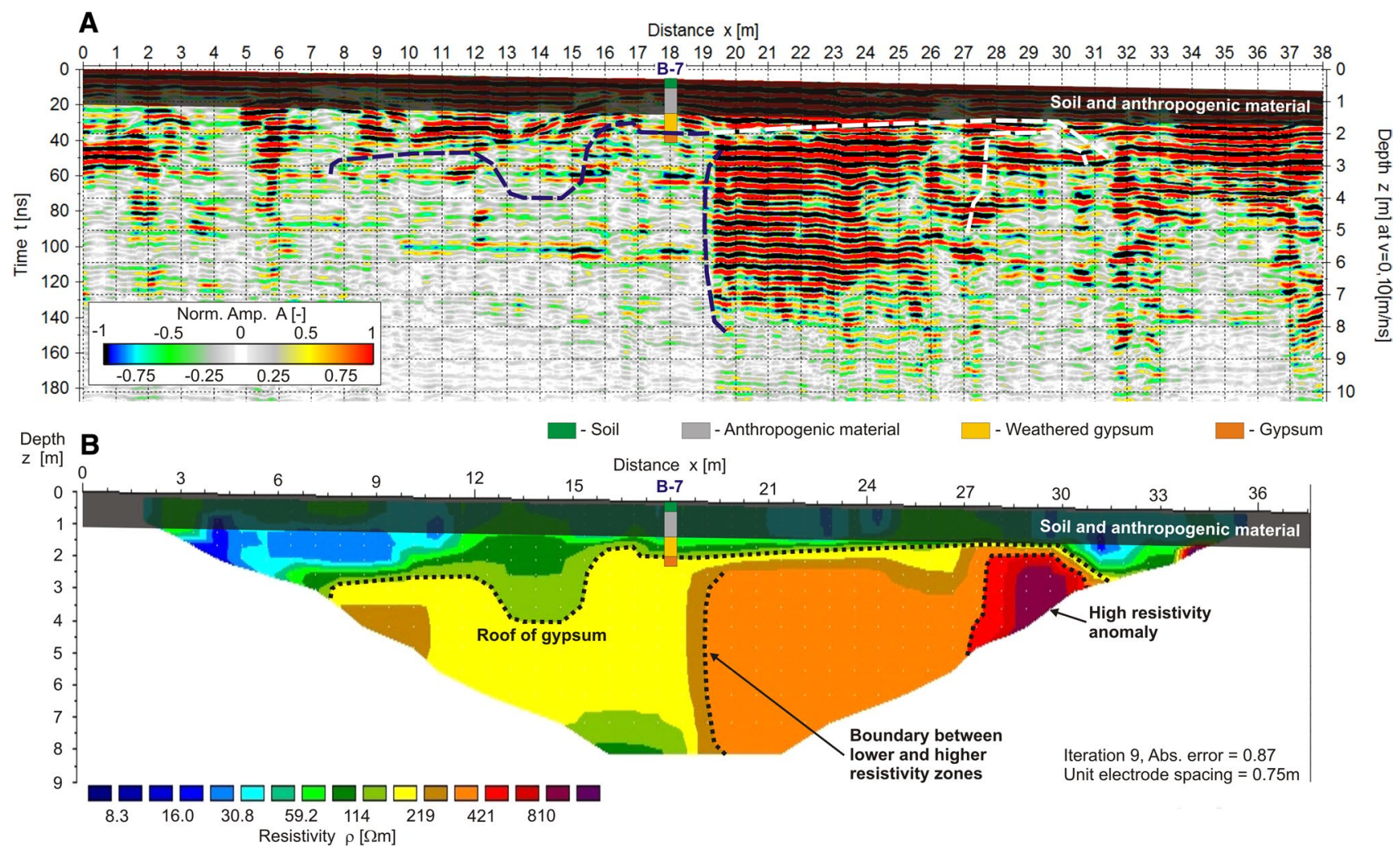

Fig. 9 a Radargram recorded in the Salt Square site, along profile GPR-1, $250 \mathrm{MHz}$ antennae; b Result of ERT surveys along profile ERT-1, Dipole-Dipole array, electrodes spacing: $1.5 \mathrm{~m}$ 
In the first part of GPR profile (Fig. 9a, between $x=0 \div 19 \mathrm{~m}$ ), amplitudes of reflections were significantly lower which was caused by an increasing of attenuation and consequently by a decreasing of resistivity (Fig. 9b-blue, green and yellow colors). Recording of lower resistivity in gypsum bedrock (Fig. 9b-yellow color) was caused by an increase in clay minerals in fractured gypsum (Fig. 2b). Recording of low resistivity in anthropogenic material and in weathered gypsum (Fig. 9b-blue and green colors) was caused by presence of clay minerals and water in the near surface zone.

The results presented in Fig. 9 depict that the most dangerous region for building foundations appear in the northwestern part of the Salt Square.

Borehole B-5, which is located the nearest to the profiles GPR-2 and ERT-2 (Fig. 8a) delivers information that to the depth of $2 \mathrm{~m}$, asphalt/pavement and anthropogenic material are located; neither weathered gypsum nor solid gypsum bedrock were revealed to the depth of $2 \mathrm{~m}$ (Fig. 8b). Considering information from borehole B-7 (Fig. 8b), which is located $3.3 \mathrm{~m}$ lower than borehole B-5 and taking into account, the result of ERT survey (Fig. 9b) roof of gypsum deposits, under profiles GPR-2 and ERT-2, should be placed at depths of c.a. $6 \div 7 \mathrm{~m}$.

In Fig. 10a, a radargram recorded near the Basilica is shown. At depths greater than $6 \div 7 \mathrm{~m}$ (i.e., at depths were gypsum bedrock should be located), two zones may be distinguished, i.e., the first zone between $x=0 \div 36 \mathrm{~m}$ and the second one between $x=36 \div 51 \mathrm{~m}$.
In the first zone, the absence of reflections is observed. In the result of ERT survey (Fig. 10b), for depths greater than c.a. $7 \mathrm{~m}$, very low resistivity was recorded, and therefore, the attenuation of electromagnetic wave caused the reduction in amplitudes of reflections. Low-resistivity anomaly may be interpreted as fractured/weathered gypsum, where fractures and porous spaces were filled with water or were colmatated with wet clay.

In the second zone, high-amplitude reflections were recorded to depth of approximately $8 \div 9 \mathrm{~m}$. High-amplitude reflections and higher resistivity in the zone between $x=36 \div 51 \mathrm{~m}$ and $z=7 \div 10 \mathrm{~m}$ depict the presence of fractured/weathered gypsum with voids filled mainly with air.

At the depths from $2 \mathrm{~m}$ to $6 \div 7 \mathrm{~m}$, high-amplitudes reflections were recorded (Fig. 10a). In this strip, three ERT anomalies with higher resistivity are easily noticed (Fig. 10b). The Basilica is located on the anthropogenic earthwork which height is c.a. $3 \mathrm{~m}$. The surrounding areas of the Basilica have been subjected to strong anthropopression from the medieval ages to XX century. Borehole B-3 (Fig. 8b) delivers information that roof of weathered gypsum is located at the depth of $1.0 \mathrm{~m}$ and roof of solid gypsum bedrock at the depth of $1.8 \mathrm{~m}$; as it was mentioned before, roof of weathered gypsum in borehole B-7 (Fig. 8b) is located at the depth of $1.1 \mathrm{~m}$ and roof of solid gypsum bedrock at the depth of $1.7 \mathrm{~m}$. Taking into account all information presented above, it is difficult to interpret unequivocally GPR and ERT anomalies, but the fact that in borehole B-5 neither weathered gypsum nor solid gypsum bedrock were revealed to the depth of $2 \mathrm{~m}$, allows to
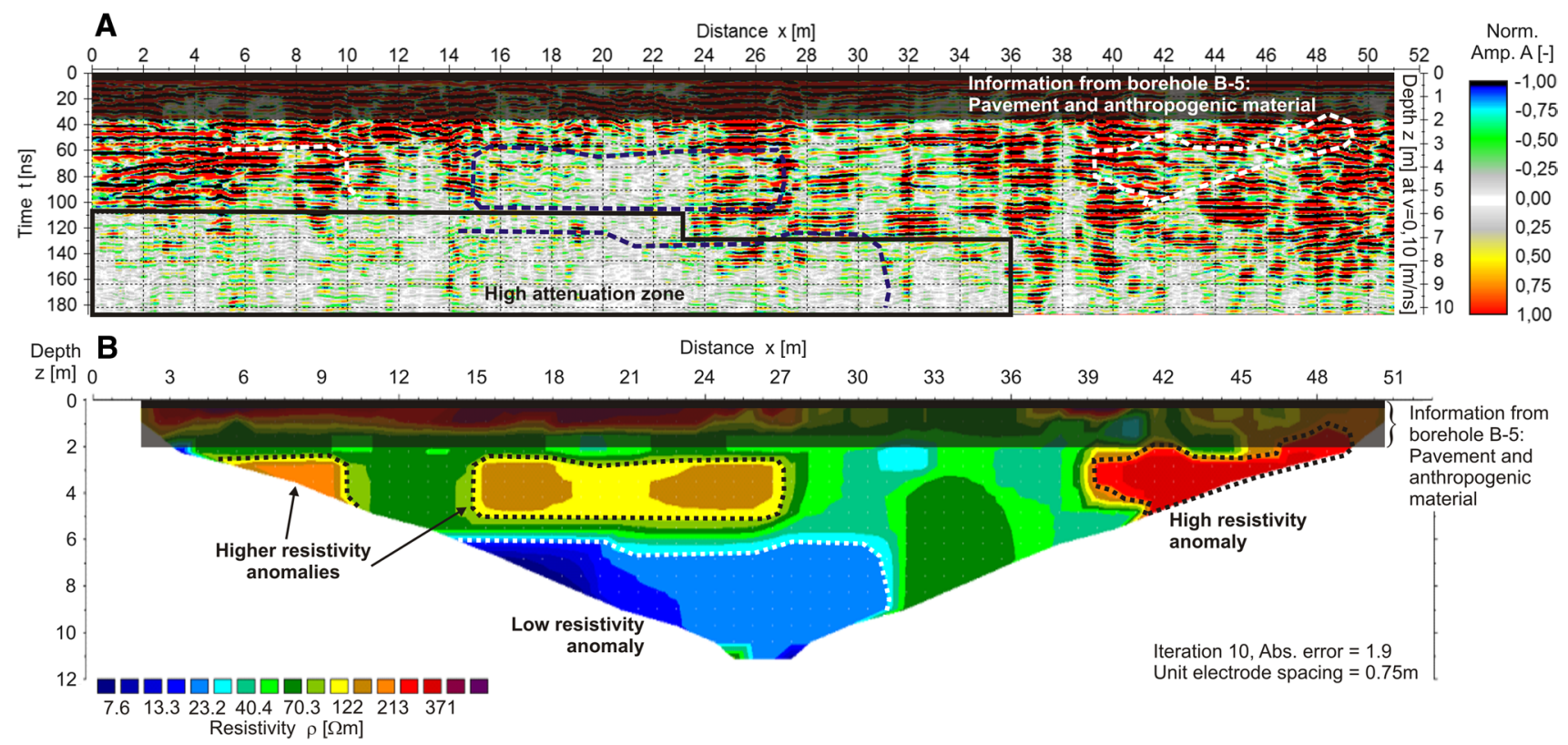

Fig. 10 a Radargram recorded on the Basilica site, along profile GPR-2, $250 \mathrm{MHz}$ antennae; b Result of ERT surveys along profile ERT-2, Dipole-Dipole array, electrodes spacing: $1.5 \mathrm{~m}$ 
A

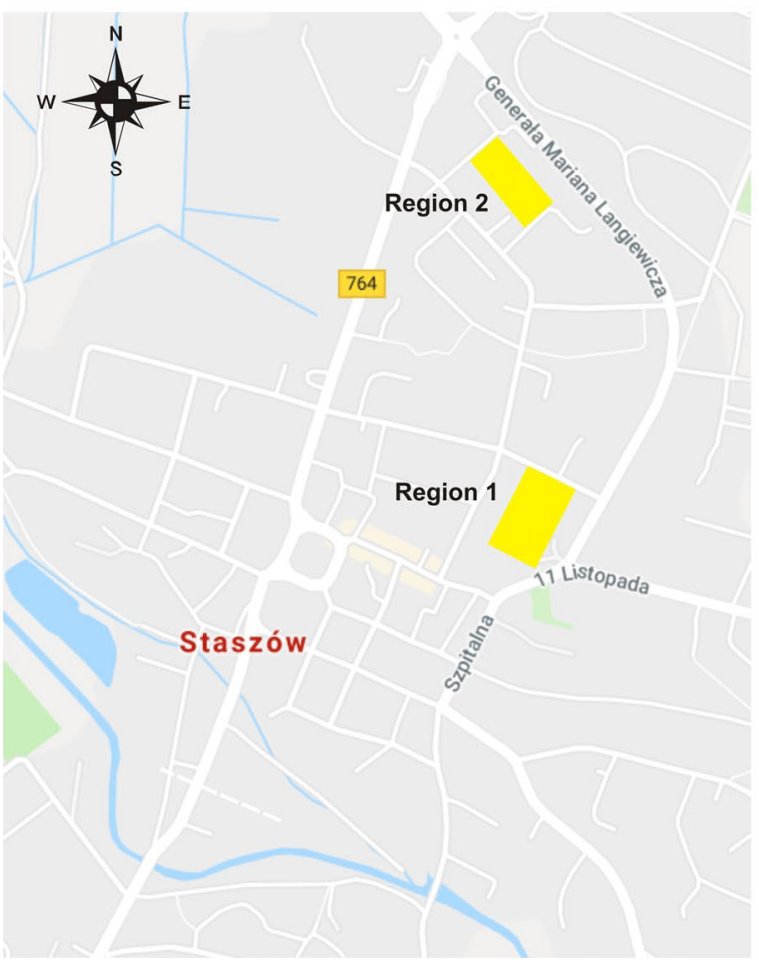

B

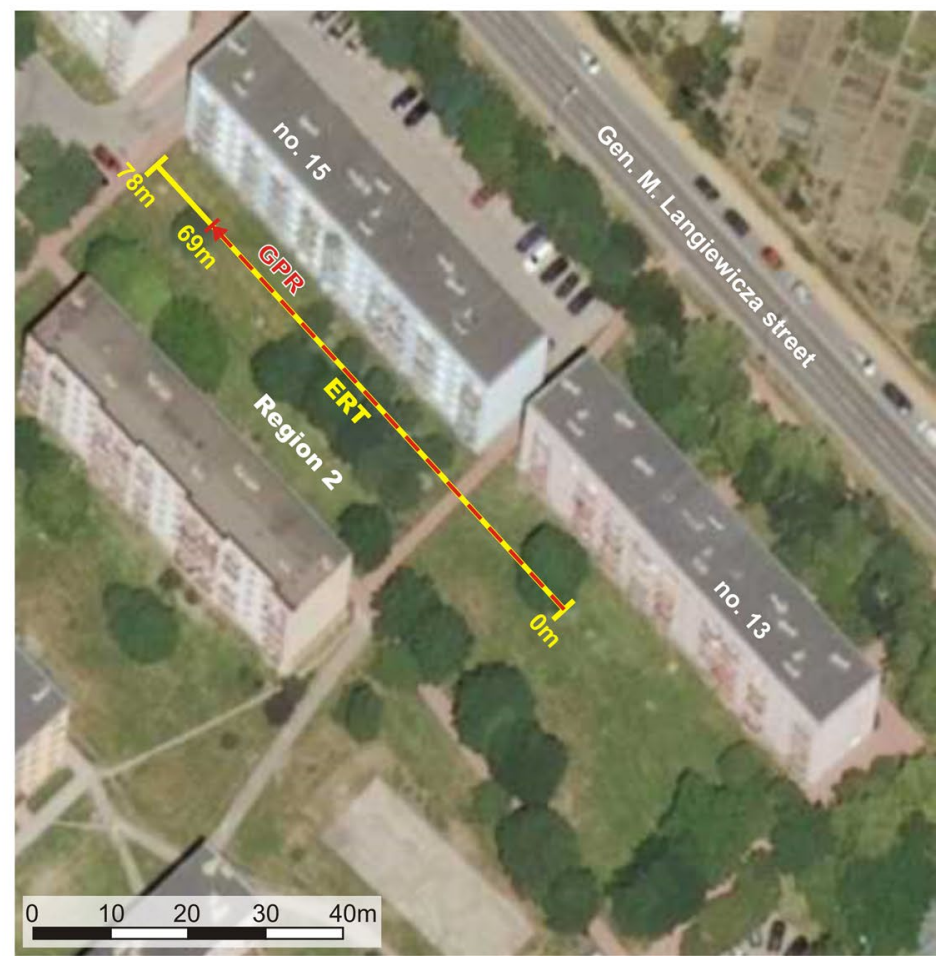

Fig. 11 a Regions of geophysical surveys in the Staszów site (base map: Google maps); b Location of selected profile in region no. 2 (base map: Google Earth Pro program)

assume that GPR and ERT anomalies at the depths between $2 \div 7 \mathrm{~m}$ have anthropogenic nature.

\section{Results from the Staszów site}

Geophysical surveys in the Staszów site were carried out along a few profiles in two regions (Fig. 11a), i.e., (1) between building of primary school and building of high school as well as (2) between buildings near Langiewicza Street. In the first region, a sinkhole generated by shallow karst forms was created; in the second site, damage (i.e., fissures) in the buildings, especially in building no. 15 (Fig. 11b), was observed. Due to the limitations of this paper, only selected results of the surveys carried out in region no. 2 (Fig. 11b) are presented in this section.

As mentioned in the introduction, geophysical investigations had to be carried out to a maximum depth of $10 \mathrm{~m}$. On the Staszów site, the surveys were conducted to the depths of $20 \mathrm{~m}$ (GPR) and $13.5 \mathrm{~m}$ (ERT), because in the low-values times (in GPR method), so-called air reflections from trees and buildings were expected; such reflections can make the interpretation difficult or even impossible. GPR measurements were taken with the use of $70 \mathrm{MHz}$ antennae, and different orientations of antennae (Fig. 3) were tested during terrain surveys. Using the ERT method, different measurement arrays were applied (Table 2) in order to analyze which array is optimal for the detection of karst forms as well as fractured and weathered gypsum bedrock occurring in this region.

In Fig. 12, the results of GPR surveys are presented. In Fig. 12a (co-pole orientation), to the depth of $10 \mathrm{~m}$ a considerable high-amplitude anomaly was recorded between $x=24 \div 60 \mathrm{~m}$, this anomaly is the superposition of the effects generated by underground objects (e.g., karst forms or anthropogenic material) and overground objects (e.g., building and trees). "Air reflections" appeared in the radargram in the low-value times, because the velocity of electromagnetic wave in the air is equal $0.3 \mathrm{~m} / \mathrm{ns}$ while in the gypsum it changes between $0.09 \div 0.12 \mathrm{~m} / \mathrm{ns}$ (Fig. 5); consequently, deeper located reflections between $x=24 \div 46 \mathrm{~m}$, below $z=8 \div 10 \mathrm{~m}$ origin, most likely, from karst forms. In Fig. 12b (cross-pole orientation), the anomaly described above is also observed. The main difference between Fig. 12a (co-pole orientation) and Fig. 12b (crosspole orientation) is that in Fig. 12b, the anomalies have a linear characteristic which may indicate the presence of horizontal cracks in gypsum. This effect is not so clearly visible in the radargram recorded with a standard orientation of antennae (Fig. 12b). 

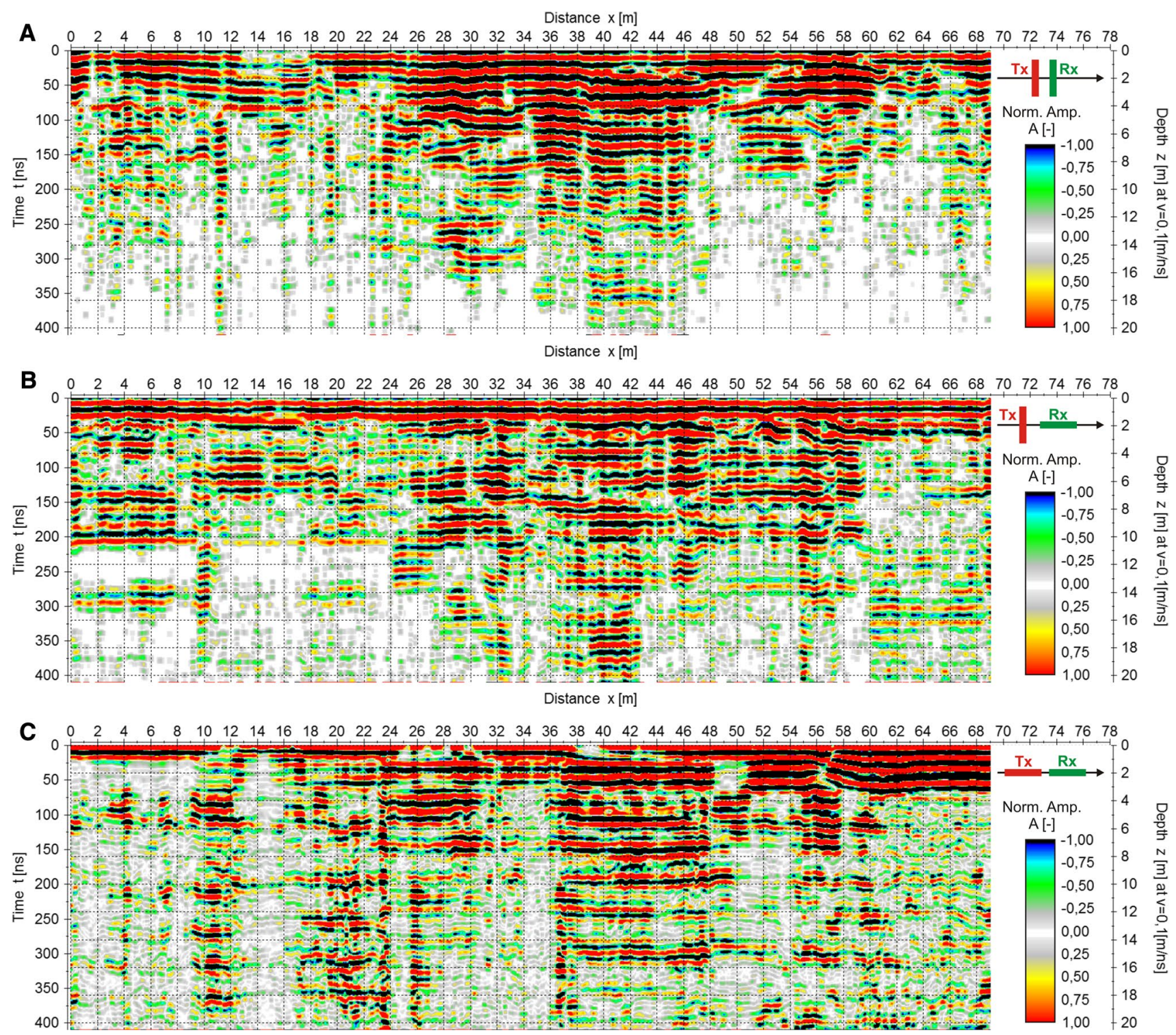

Fig. 12 Radargrams recorded along profile named GPR (Fig. 11b) for the following antennae orientations: a co-pole; b cross-pole; c end-fire

Additionally, in Fig. 12b a gain of amplitudes in lowvalue times is not visible, i.e., between $x=24 \div 60 \mathrm{~m}$, where the superposition of reflections from underground and overground objects appeared; consequently, a radargram is easier for visual interpretation and "air reflections" do not disturb markedly the interpretation.

The least valuable results of the GPR surveys were obtained along profile named GPR using of the end-fire orientation antennae (Fig. 12c) but the main anomalies are still visible.

As it was mentioned formerly, the reflection coefficient depends on the contrast of electrical properties and orientation of antennae. Depending on site (i.e., geological conditions and level of disturbances), type of underground object and its parameters and geometry, usually only one, selected orientation of GPR antennae delivers satisfied result; sometimes it is a co-pole orientation, in other site it is an end-fire orientation and in the third site a cross-pole orientation may deliver the better results. Fractures and karst forms have stochastical distribution in the geological medium, they have usually complicated shape and their petrophysical parameters may change markedly in distance of a few meters depending of medium filling of free spaces. Therefore, there is not one universal orientation of GPR antenna and different orientations of antennae should be tested during detection of fractured zones and karst forms. In the Staszów site, the most suitable orientation of GPR antennae for fractures and karst forms detection seems to be a cross-pole orientation.

In Fig. 13, the results obtained from the ERT surveys are presented. In the central part of the ERT profile, between 


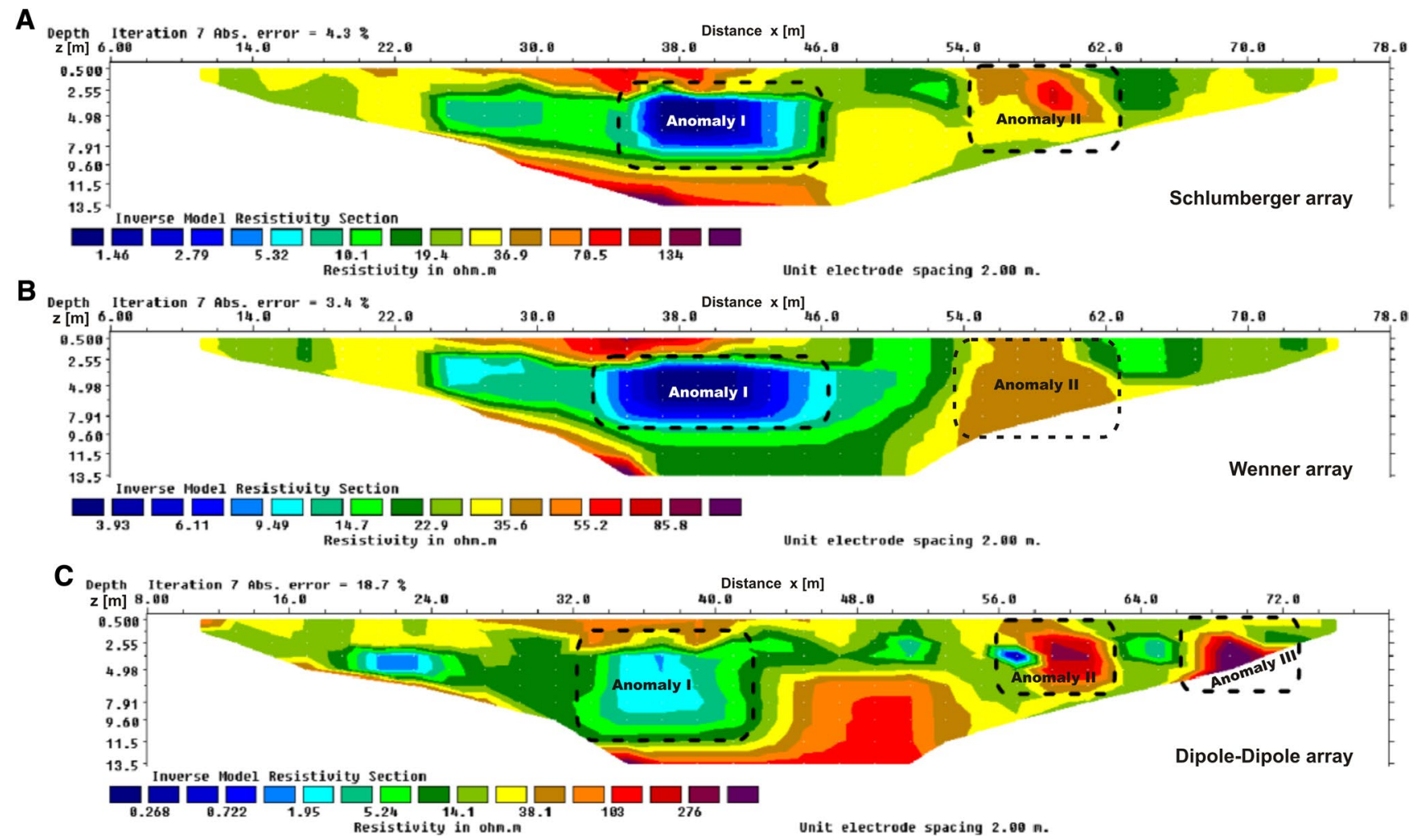

Fig. 13 Distributions of resistivity (after inversion) for the following measurement arrays: a Schlumberger; b Wenner; c Dipole-Dipole

$x=24 \mathrm{~m}$ and $x=46 \div 48 \mathrm{~m}$, a decreasing of resistivity is observed and a clearly visible anomaly, called "Anomaly I," may be distinguished. The decrease in resistivity in "Anomaly I" should influence the increase in attenuation of electromagnetic waves and, in consequence, no reflections should be observed in radargrams. In fact, in Fig. 12, the opposite effect is observed, i.e., in an area with very low resistivity, the amplitudes of reflections are high. This effect may be interpreted as following: high-amplitude reflections between $x=34 \div 46 \mathrm{~m}$ to a depth of approximately $8 \mathrm{~m}$ (Fig. 12) originate mainly from overground objects. GPR anomalies recorded on the left and right sides of "Anomaly I" and under it, originate from underground objects. "Anomaly II" (Fig. 13) correlates with high-amplitude reflections recorded vertically in Fig. $12 \mathrm{~b}$ and c, between $x=54 \div 62 \mathrm{~m}$. "Anomaly III" (Fig. 13c) was difficult to interpret because it appeared only for the Dipole-Dipole array and it was not recorded in radargrams, due to short profiles (Fig. 12).

In general, the detailed interpretation of the results of geophysical surveys is as follows: (a) Gypsum is probably divided into horizontal blocks or the horizontal fracturing occurred in the rock mass; (b) the low resistivity medium is either fractured/ weathered gypsum filled with Quaternary material or a mixture of Quaternary and anthropogenic materials; (c) the very low resistivity "Anomaly I" is a zone filled with water; (d) the most unsafe area for the buildings is the region of "Anomaly I" due to presence of water in weathered/fractured/loose geological medium where suffosion processes may be developed.

\section{Conclusion}

The results of the research presented in this paper show that selected geophysical methods can be successfully applied to the detection of karst forms occurring in gypsum. Due to the spatial and stochastical distribution of karst forms as well as fractured and weathered bedrock, measurements should be carried out in 3D mode, at it was shown for the Siesławice site. In terms of building development, it is important to detect karst forms and fractured zones developed in the vicinity to a depth of a few meters, i.e., around and directly under the foundations of buildings.

For this purpose, the high-resolution, fast, low time- and labor-consuming GPR method appears to be optimal but other auxiliary methods have to be applied for reduction in interpretation ambiguity. In GPR method, it is very important to test different antennae orientations to obtain the best measurement results for further interpretation. The GPR method can be limited by the presence of materials with low resistivity (and consequently a high attenuation) in the geological medium, e.g., clays, loams, mineralized water. In urbanized areas, an additional limitation of the GPR method 
can also be interference from overground objects and underground infrastructure. The application of shielded antennae only partly protects against such interference.

In such situations, the GPR method should be replaced with the much more time- and labor-consuming ERT technique, and however, this should provide positive results in geological media with low resistivity and is not so sensitive to anthropogenic interferences. The ERT method also has its limitations, e.g., in urbanized areas, terrain surface is often covered with asphalt, concrete or pavement which makes it impossible to insert electrodes into the ground.

If GPR and ERT methods cannot be used, other geophysical techniques should be applied for the noninvasive detection of karst forms, e.g., microgravimetry, conductometry or CCR (Capacitively Coupled Resistivity) method. In order to reduce interpretation ambiguity, at least two of the abovementioned methods should be used simultaneously.

Acknowledgements This paper was financed by Cracow University of Technology, amongst others, as part of the Projects: Ś-2/372/2013/ DS and Ś-2/299/2016/DS (the Wiślica site) and Ś-2/335/2017/DS (the Staszów site).

Open Access This article is distributed under the terms of the Creative Commons Attribution 4.0 International License (http://creativeco mmons.org/licenses/by/4.0/), which permits unrestricted use, distribution, and reproduction in any medium, provided you give appropriate credit to the original author(s) and the source, provide a link to the Creative Commons license, and indicate if changes were made.

\section{References}

Annan AP (1999) Practical processing of GPR data. Sensor \& Software Inc., Canada

Annan AP (2001) Ground penetrating radar-workshop notes. Sensor $\&$ Software Inc., Canada

Bąbel M (1999) History of sedimentation of the Nida gypsum deposits (middle Miocene, Carpathian foredeep, southern Poland). Geol Q 43(4):429-447

Bąbel M, Olszewska-Nejbert D, Nejbert K, Ługowski D (2015) The Badenian evaporative stage of the Polish Carpathian Foredeep: sedimentary facies and depositional environment of the selenitic Nida Gypsum succession. In: Proceedings of 31st IAS meeting of sedimentology, Cracow, Poland

Chalikakis K, Plagnes V, Guerin R, Valois R, Bosch FP (2011) Contribution of geophysical methods to karst-system exploration: an overview. Hydrogeol J 19:1169-1180

Cichy K (2014) Kompleksowe badania geofizyczne na stanowiskach archeologicznych. Praca magisterska, promotor T. Gołębiowski, WGGiOŚ AGH, Kraków (unpublished) (in Polish)

Daniels JJ, Wielopolski L, Radzevicius S, Bookshar J (2003) 3D GPR polarization analysis for imaging complex objects. In: Proceedings of 16th SAGEEP conference, San Antonio, USA

Derobert X, Abraham O (2000) GPR and seismic imaging in a gypsum quarry. J Appl Geophys 45:157-169

Documentation (2018) Wykonania niedestrukcyjnych badań archeologicznych przeprowadzonych z użyciem przynajmniej dwóch nieinwazyjnych metod pomiarowych terenu placu przykościelnego w Wiślicy (działka nr 437) w ramach projektu "Modernizacja
Muzeum Archeologicznego w Wiślicy jako oddziału Muzeum Narodowego w Kielcach wraz z otoczeniem w celu zabezpieczenia i ochrony unikatowych obiektów dziedzictwa narodowego". Opracowanie: firma MET-GEO, Trzebinia (unpublished), (in Polish)

Drożdzak R, Twardowski K (2010) Przenikalność dielektryczna ośrodków porowych-czynniki wpływające na jej zmienność. Wiertnictwo - Nafta-Gaz 27(1-2):111-120 (in Polish)

Fils J (1954) Kras gipsowy Niecki Nidziańskiej. Prace geograficzne nr 1, Instytut Geografii PAN, PWN, Warszawa (in Polish)

Gołębiowski T (2008) Changeable-offset GPR profiling for loose zones detection in the levees. In: Proceedings of 14th European meeting of environmental and engineering geophysics, Cracow, Poland

Gołębiowski T (2012) Zastosowanie metody georadarowej do detekcji i monitoringu obiektów o stochastycznym rozkładzie w ośrodku geologicznym, Rozprawy - Monografie AGH, Kraków (in Polish)

Gołębiowski T (2014) Dokumentacja badań georadarowych przeprowadzonych na działce nr 923 w Wiślicy. Ekspertyza dla UM w Wiślicy (unpublished), (in Polish)

Gołębiowski T, Tomecka-Suchoń S (2012) GPR fractures detection using changeable antennae orientation. In: Proceedings of 5th Saint Petersburg international conference and exhibition, Saint Petersburg, Russia

Gołębiowski T, Pasierb B, Porzucek S, Łój M (2018a) Complex prospection of medieval underground salt chambers in the village of Wiślica, Poland. Archaeol Prospect 25(3):243-254

Gołębiowski T, Pasierb B, Kiełtyka-Sołtysiak G (2018b) Metody geofizyczne w ochronie dziedzictwa archeologicznego Wiślicy. In: Materiały konferencji "Metody geofizyczne w archeologii polskiej”, Toruń (in Polish)

Guinea A, Playa E, Rivero L, Himi M, Bosch R (2010) Geoelectrical classification of gypsum rocks. Surv Geophys 31:557-580

Guy ED, Daniels JJ, Radzevicius S (1999) Demonstration of using crossed dipole GPR antennae for site characterization. Geophys Res Lett 26(22):3421-3424

Łój M, Gołębiowski T, Porzucek S (2014) Geophysical surveys and modelling for recognizing of gypsum karst. Geoinform Pol 13:83-97

Loke MH (1999) Electrical imaging surveys for environmental and engineering studies-a practical guide to 2-D and 3-D surveys. Geometrics Ltd, Scottsdale

Loke MH (2018) Tutorial: 2D and 3D electrical imaging surveys. Geotomo Software, Penang

Ługowski D, Jarzyna A, Bąbel M, Nejbert K (2016) Metody dokumentowania zastosowane $\mathrm{w}$ badaniach terenowych stanowiska wietrzejących anhydrytów w Piskach k. Lwowa. Biuletyn Państwowego Instytutu Geologicznego 466:201-214 (in Polish)

Manoutsoglou E, Vachlas G, Panagopoulos G, Hamdan H (2010) Delineation of gypsum/anhydrite transition zone using electrical tomography. A case study in an active open pit, Altsi, Crete, Greece. J Balk Geophys Soc 13(2):21-28

Marcak H, Gołębiowski T (2010) Analiza możliwości detekcyjnych metody GPR dla zmiennej geometrii układu pomiarowego. In: Materiały konferencji "Geofizyka w Geologii i Górnictwie", Sosnowiec-Zawiercie (in Polish)

McCormack T, O'Connell Y, Daly E, Gill LW, Henry T, Perriquet M (2017) Characterisation of karst hydrogeology in Western Ireland using geophysical and hydraulic modelling techniques. J Hydrol Reg Stud 10:1-17

Ornacka S (2014) Georadarowe obrazowanie 3D zjawisk krasowych. Praca inżynierska, promotor T. Gołębiowski, WGGiOŚ AGH, Kraków (unpublished), (in Polish)

Pasierb B, Gołębiowski T, Łój M, Porzucek S, Cichy K, Pacek B (2014) Czy pod placem solnym w Wiślicy składowano sól? In: Materiały konferencji "Metody geofizyczne w archeologii polskiej”, Kraków (in Polish) 
Plewa M, Plewa S (1992). Petrofizyka. Wydawnictwa Geologiczne, Warszawa (in Polish)

Porzucek S, Łój M, Matwij K, Matwij W (2018) Modern geodetic measurement techniques in gravimetric studies on the example of Gypsum Karst in the Siesławice Region. In: Proceeding of conference "POL-VIET 2017", E3S Web of Conferences, no. 35

Prokhorenko V, Ivashchuk V, Korsun S, Stefanyshyn I (2006) Ground penetrating radar survey in Podil'lya Karst Area-Ternopil Region, Ukraine. In: Proceeding of 11th international conference on GPR, Columbus, Ohio, USA

ReflexW Manual (2018) SandeierGeo firm. Karlsruhe, Germany

Roberts RL, Daniels JJ (1999) Analysis of GPR polarization phenomena. J Environ Eng Geophys 1(2):139-157

Rudzki M (2015) Zastosowanie metody tomografii elektrooporowej do lokalizacji struktur krasowych. Geofizyka Toruń Company (in Polish)

Silverii F, D’Agostino N, Borsa AA, Calcaterra S, Gambino P, Giuliani R, Mattone M (2019) Transient crustal deformation from karst aquifers hydrology in the Apennines (Italy). Earth Planet Sci Lett 506:23-37
Sowiński J (2009) Opinia geotechniczna pod przebudowę Rynku i budowę Pawilonu Archeologicznego w Wiślicy. Sowiński-usługi geologiczne, Kielce (in Polish)

Stokes T, Griffiths P, Ramsey C (2010) Karst geomorphology, hydrology and management. In: Compendium of forest hydrology and geomorphology in British Columbia, Land management handbook. vol 66, pp 373-400

Ulugergerli E, Akca I (2006) Detection of cavities in gypsum. J Balk Geophys Soc 9(1):8-19

Urban J, Chwalik-Borowiec A, Kasza A (2015) Warunki rozwoju i wiek krasu w gipsach Niecki Soleckiej. Biuletyn Państwowego Instytutu Geologicznego 462:125-152 (in Polish)

Watlet A, Kaufmann O, Triantafyllou A, Poulain A, Chambers JE, Meldrum PI, Wilkinson PB, Hallet V, Quinif Y, Van Ruymbeke M, Van Camp M (2018) Imaging groundwater infiltration dynamics in the karst vadose zone with long-term ERT monitoring. Hydrol Earth Syst Sci 22:1563-1592 